Delft University of Technology

\title{
Investigation of Soil-Arching Development in Dense Sand by 2D Model Tests
}

Rui, Rui; van Tol, Frits; Xia, YY; van Eekelen, SJM; Hu, G

DOI

10.1520/GTJ20150130

Publication date

2016

Document Version

Final published version

Published in

Geotechnical Testing Journal

\section{Citation (APA)}

Rui, R., van Tol, F., Xia, YY., van Eekelen, SJM., \& Hu, G. (2016). Investigation of Soil-Arching Development in Dense Sand by 2D Model Tests. Geotechnical Testing Journal, 39(3), 415-430. https://doi.org/10.1520/GTJ20150130

\section{Important note}

To cite this publication, please use the final published version (if applicable).

Please check the document version above.

\section{Copyright}

Other than for strictly personal use, it is not permitted to download, forward or distribute the text or part of it, without the consent of the author(s) and/or copyright holder(s), unless the work is under an open content license such as Creative Commons.

\section{Takedown policy}

Please contact us and provide details if you believe this document breaches copyrights.

We will remove access to the work immediately and investigate your claim. 


\section{Geotechnical Testing Journal}

R. Rui, ${ }^{1}$ A. F. van Tol, ${ }^{2}$ Y. Y. Xia, ${ }^{3}$ S. J. M. van Eekelen, ${ }^{4}$ and G. $H u^{5}$

DOI: 10.1520/GTJ20150130

Investigation of Soil-Arching Development in Dense Sand by 2D Model Tests 
Manuscript received June 18, 2015; accepted for publication November 9 , 2015; published online February 3, 2016.

School of Civil Engineering and Architecture, Wuhan Univ. of Technology, Luoshi Rd. 122, 430070 Wuhan, People's Republic of China, e-mail: r.rui@whut.edu.cn; ruigrate@126.com

2 Dept. of Geoscience and Engineering, Faculty of Civil Engineering and Geosciences, Delft Univ. of Technology, Stevinweg 1, 2628 GA Delft, The Netherlands, e-mail: a.f.vantol@tudelft.nl

${ }^{3}$ School of Civil Engineering and Architecture, Wuhan Univ. of Technology, Luoshi Rd. 122, 430070 Wuhan, People's Republic of China, e-mail: xiayy1965@126.com

${ }^{4}$ Deltares, Unit Geo-Engineering, P.O. Box 177, 2600 MH Delft, The Netherlands, e-mail: suzanne.vaneekelen@deltares.nl

${ }^{5}$ School of Civil Engineering and Architecture, Wuhan Univ. of Technology, Luoshi Rd. 122, 430070 Wuhan, People's Republic of China, e-mail: 837521922@qq.com
R. Rui, ${ }^{1}$ A. F. van Tol, ${ }^{2}$ Y. Y. Xia, ${ }^{3}$ S. J. M. van Eekelen, ${ }^{4}$ and G. $\mathrm{Hu}^{5}$

\section{Investigation of Soil-Arching Development in Dense Sand by 2D Model Tests}

\section{Reference}

Rui, R., van Tol, A. F., Xia, Y. Y., van Eekelen, S. J. M., and Hu, G., "Investigation of Soil-Arching

Development in Dense Sand by 2D Model Tests," Geotechnical Testing Journal

doi:10.1520/GTJ20150130. ISSN 0149-6115

\section{ABSTRACT}

A trapdoor system has frequently been used to study soil arching and its development in recent years. The load transfer in the fill of piled embankments is very similar to a trapdoor system with multiple trapdoors. There are multiple arching models described in different standards and guidelines for piled embankments that can be subdivided into three archingmodel families. To study the soil-arching type and its development, a series of model tests with sand fills were carried out in a two-dimensional (2D) multi-trapdoor test setup. The tests considered four factors-the fill height, trapdoor width, pile width, and grain size of the sand-with four values for each factor. Triangular slip surfaces were found at very small deformations using the particle image velocimetry (PIV) technique. These surfaces evolved in ways that could be related to the three types of stress-distribution ratio curves, with development patterns similar to the arching families of piled embankments: (1) the rigidmodel family, (2) the equal-settlement-plane-model family, and (3) the limit-equilibriummodel family. The limit-equilibrium-model family occurred in tests with narrow trapdoor widths.

\section{Keywords}

trapdoor tests, soil arching, piled embankments, multiple trapdoors, model test, stress-distribution ratio, PIV technique

\section{Introduction}

Trapdoor systems are often used to study arching mechanisms (Terzaghi 1936), and the test setups have become the standard in many studies (Ladanyi and Hoyaux 1969; Vardoulakis et al. 1981; Sloan et al. 1990; Paikowsky and Tien 2002). Similar trapdoor systems have been used to study soil arching in real geotechnical problems. Meguid et al. (2008) presented testing techniques 
ranging from two-dimensional (2D) trapdoor tests to miniature tunnel-boring machines that simulate tunnel excavations. Costa et al. (2009) conducted three-dimensional (3D) tests to study the deformation patterns and failure mechanisms of sand over a deep active trapdoor (buried pipe). Well-defined failure surfaces were identified in the sand fill with the displacement of the trapdoor. The boundary conditions of piled embankments match well to the multiple-trapdoor system. The arching mechanism becomes more complicated when the pile width $a$ is taken as a variable. Van Eekelen et al. (2012a, 2012b, 2013, 2015) used a series of tests with a 3D trapdoor-like setup to create an analytical arching model for geosynthetic reinforcement design using a saturated, leak-proof foam cushion between the piles with an attached tap. Opening the tap and applying pressure to the saturated foam cushion squeezed out the water, simulating the compression of soft soil. Eskişar et al. (2012) studied arching in reinforced and unreinforced piled embankments with the $\mathrm{x}$-ray computed tomography (CT) method by constructing small, 3D scale models of piled embankments with different fill materials and pile spacings. Different arch shapes denoting the density change of the materials for different test cases were shown in the CT images.

The deformation patterns and development processes during the movement of the trapdoor are very important for establishing a comprehensive understanding of soil arching. Terzaghi $(1936,1943)$ found slip surfaces in the fill of the trapdoor tests. Terzaghi (1943) suggested that the inclination of the slip surfaces decreases from $90^{\circ}$ to $45^{\circ}+\varphi / 2$ with increasing $H /(s-a)$, where $H$ is the height of the fill, $s$ is the spacing, and $a$ is the width of the trapdoor. The changing slip-surface angle shows the arching development. Chen et al. (2008) carried out a series of model tests of piled embankments with and without reinforcement. In the unreinforced piled embankments tests (nos. $1 \sim 7)$, the pile width $a$ was $150 \mathrm{~mm}$ and the net spacing $(s-a)$ was $600 \mathrm{~mm}$; $H$ varied from $420 \mathrm{~mm}$ to $1200 \mathrm{~mm}$. Settlement was modeled by the discharge of two water bags. Differential settlement occurred on the top of the embankment in test nos. 1 to $4(H /(s-a) \leq 1.4)$. In tests nos. 5 to $7(H /(s-a) \geq 1.6)$, an equal settlement plane and no apparent differential settlement occurred on the embankment surfaces. However, the soilarching development patterns are not well described because most of the arching patterns observed in the tests occurred at the end of settlement. In recent years, several researches have started focusing on the arching development during the ongoing movement of the trapdoor. Chevalier et al. (2012) conducted a series of single trapdoor tests with $a=0.20 \mathrm{~m}$, and $H=0.15$ to $0.80 \mathrm{~m}$. They described the load-transfer processes during the downward movement of the trapdoor in three phases: phase (a): the maximum transfer phase, phase (b): the transitional phase, and phase (c): the critical phase. A triangular expansion zone was observed in phase (b), whereas phase (c) showed vertical sliding zone boundaries. Iglesia et al. (2013) carried out a series of centrifuge tests of piled embankments and also identified three development stages. Based on the displacement data, they concluded that the physical arch evolves from an initially curved configuration to a triangular shape, and ultimately to a prismatic sliding mass with vertical sides. The triangular zone of transitional phase [phase (b)] and final vertical boundaries [phase (c)] in Chevalier et al. (2012) partly coincide with the last two stages described in Iglesia et al. (2013). Both studies confirmed the inclination change suggested by Terzaghi $(1936,1943)$. The development patterns may be different under different geometric combinations, and the arching development processes have not been adequately studied.

For the study of soil-arching development, the whole displacement of the fill must be measured. The advantages of the two-dimensional (plane strain) test are that the deformation can be observed and/or recorded through a transparent panel. To explore the different development patterns of soil arching and determine where and when they are applicable, a plane strain multi-trapdoor test setup was built. Four factors-fill height $(H)$, net spacing $(s-a)$, width of the piles $(a)$, and grain size of the sand $(d)$-were taken into account. It is expected that the tests results will show the different arching types and development patterns. Analysis of these arching patterns and geometric conditions will be used for further development of analytical arching models.

\section{Available Arching Models for Piled Embankments}

There are many analytical models available to model arching effects in piled embankments. These models are used to calculate the load acting directly on the pile, which denoted as arching or "load part A" in studies by Van Eekelen et al. (2011, 2012a, 2012b). Different design guidelines use different models. BS8006-1 (2010) combines Terzaghi's theory with Marston and Anderson's (1913) experimental results. DGGT (2011) and CUR 226 (2010) use the research of Zaeske (2001), Zaeske and Kempfert (2002), and Kempfert et al. (2004), who describe the arch in piled embankments as a "multi-arch." The modified guideline CUR 226 (2016) uses the research of Van Eekelen et al. (2013, 2015), who described the arches in piled embankments as concentric arches. The fictitious inclusion method and diffusion cone method are laid out in the IREX (2012). In the case of embankments, the fictitious inclusion method is equivalent to the Terzaghi (1943) method. The diffusion cone method uses a kinematic approach that treats a trapezoidal block on the subsoil as a rigid block. These different methods result in values for arching, which clearly differ from one another (Van Eekelen et al. 2013). Current standards and guidelines do not provide general guidance on the applicability of each method, because each model is determined from mechanical models under 
FIG. 1

Soil-arching model families

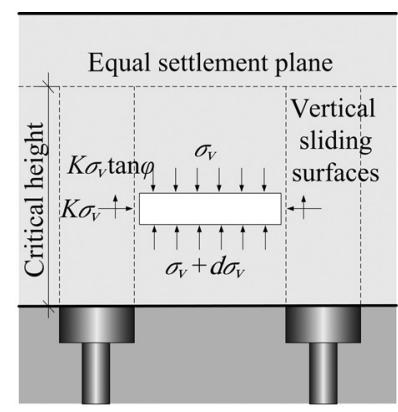

(a) The equal settlement model family

( $\sigma_{V}$ is the vertical stress and $K$ is the coefficient of lateral earth pressure) specific conditions. The calculation methods in the currently available standards and guidelines are usually members of one of the following three model families.

The first model family consists of frictional models (see Fig. 1(a)) based on the principles of Terzaghi (1943). In this frictional model, the key elements are the equal settlement plane and the vertical shear planes. The load is transferred to the pile through two vertical shear planes until the critical height is reached.

The second model family consists of rigid models (see Fig. 1(b)). This model family considers two rigid blocks with a trapezoidal or triangular shape on and between the piles. These models have been validated by model tests (Chevalier et al. 2012) and discrete element method (DEM) simulations (Le Hello and Villard 2009; Chevalier et al. 2010). However, the inclination of the blocks differs between researchers because of different assumptions and methodologies. Carlsson (1987) and Rogbeck et al. (1998, modified by Van Eekelen et al. 2003) propose an inclination of $75^{\circ}$, Guido et al. (1987) suggests a pyramid with

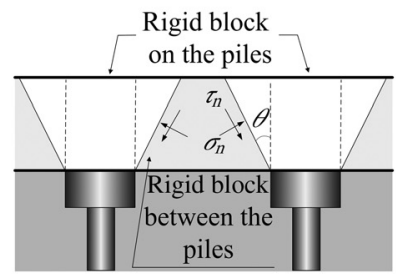

(b) The rigid model family $\left(\sigma_{n}\right.$ and $\tau_{n}$ are the normal and the tangential stresses acted on the boundary, respectively)

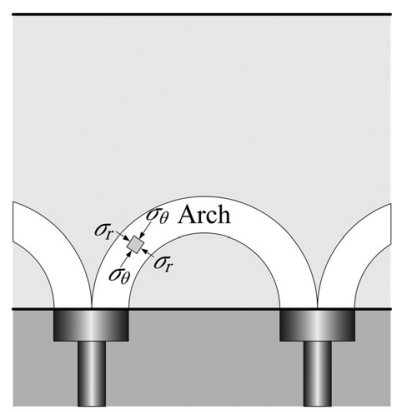

(c) Limit equilibrium model family

$\left(\sigma_{\theta}\right.$ and $\sigma_{r}$ are the axial and the radial stresses) an angle of $45^{\circ}$, and IREX (2012) adopts the $90^{\circ}-\varphi$, where $\varphi$ is the friction angle of the fill. The SINTEF method (Oiseth et al. 2002) gives an angle ranging between $68^{\circ}$ and $74^{\circ}$, and considers a variety of different soils used in embankments.

The third model family considers limit equilibrium models (see Fig. 1(c)). Hewlett and Randolph (1988) first suggested hemispherical and circular arches based on 2D trapdoor tests. Many modifications have been suggested for this arching model based on numerical simulations or experiments. Examples of these modifications include the multi-arch model (Zaeske 2001) and the concentric arch model (Van Eekelen et al. 2013), which was developed for piled embankments with basal geosynthetic reinforcement.

\section{Test Setup and Testing Program}

\section{TEST SETUP}

Tests were conducted using the plane strain box shown in Fig. 2. The particle image velocimetry (PIV) technique was used

FIG. 2 Cross-section view, plan view, and photo of the test setup.

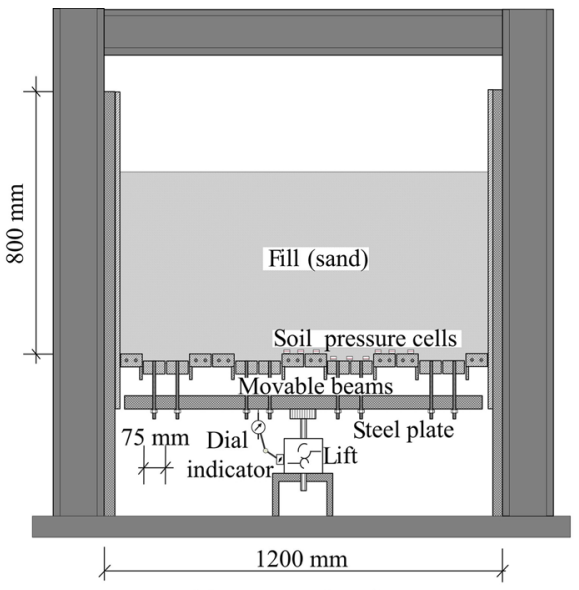

(a) Cross section view

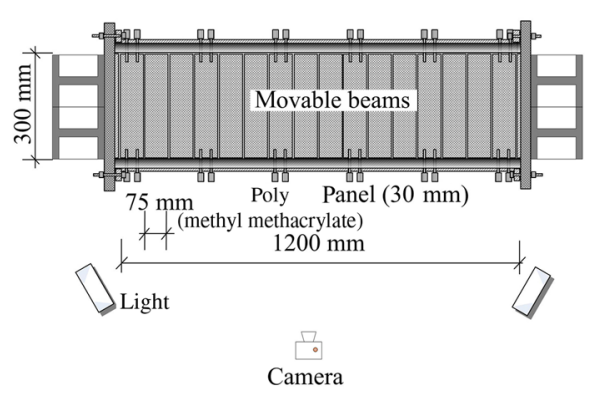

(b) Plan view

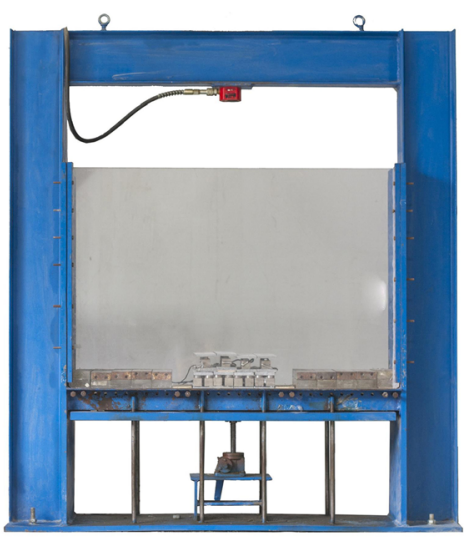

(c) Photo 
to measure displacement of the sand through the poly(methyl methacrylate) panel.

This apparatus consisted of two main parts: the sand chamber and the moving components. The inner dimensions of the sand chamber were $1200 \mathrm{~mm} \times 800 \mathrm{~mm} \times 300 \mathrm{~mm}$ (length $\times$ height $\times$ width). The bottom was supported by steel beams and the sides were steel boards welded to the frame of the apparatus. Movement of the trapdoor could be controlled by using the 16 movable steel beams, heavy steel plate, lift, dial indicator, and some screws (Fig. 2). Each movable beam could be fixed either to the frame to simulate a pile, or connected to the heavy steel plate through the screws to simulate settling soil. The lift was used to support the heavy plate and to move the beams downward. The amount of settlement can be monitored precisely with the dial indicator. This test setup allowed the possibility of more than 30 test setups with varying trapdoor and beam widths.

The variables chosen for the tests were the fill height $(H)$, net spacing $(s-a)$, the width of the piles $(a)$, and grain size $(d)$. Grain size was selected as a factor because jamming in the fill is usually more evident with larger grains, which could increase arching. Four values were chosen for each factor. $H,(s-a)$, and $a$ were chosen according to the size of the test setup and set at equal intervals. The four levels for $H$ are (1) $150 \mathrm{~mm}$, (2) $300 \mathrm{~mm}$, (3) $450 \mathrm{~mm}$, and (4) $600 \mathrm{~mm}$. The four levels for $(s-a)$ and $a$ are same, which are (1) $75 \mathrm{~mm}$, (2) $150 \mathrm{~mm}$, (3) $225 \mathrm{~mm}$, and (4) $300 \mathrm{~mm}$. The four levels for $d$ are (1) $0.25 \sim 0.425 \mathrm{~mm}$, (2) $0.425 \sim 1.0 \mathrm{~mm}$, (3) $1.0 \sim 1.4 \mathrm{~mm}$, and (4) $1.4 \sim 2.00 \mathrm{~mm}$, respectively. However, testing all combinations of the factors would have resulted in an unreasonable number of tests for our scope, and thus the number of tests was limited using the

TABLE 1 Optimization of the test parameters.

\begin{tabular}{|c|c|c|c|c|}
\hline Test & $\begin{array}{l}\text { Height } \\
H(\mathrm{~mm})\end{array}$ & $\begin{array}{c}\text { Trapdoor } \\
\text { Width }(s-a)(\mathrm{mm})\end{array}$ & $\begin{array}{l}\text { Pile Width } \\
a(\mathrm{~mm})\end{array}$ & $\begin{array}{l}\text { Diameter of } \\
\text { Sand } d(\mathrm{~mm})\end{array}$ \\
\hline 1 & $150(1)$ & $75(1)$ & $75(1)$ & $0.25 \sim 0.425(1)$ \\
\hline 2 & $150(1)$ & $150(2)$ & $150(2)$ & $0.425 \sim 1.0(2)$ \\
\hline 3 & $150(1)$ & $225(3)$ & $225(3)$ & $1.0 \sim 1.4(3)$ \\
\hline 4 & $150(1)$ & $300(4)$ & $300(4)$ & $1.4 \sim 2.00(4)$ \\
\hline 5 & $300(2)$ & $75(1)$ & $150(2)$ & $1.0 \sim 1.4(3)$ \\
\hline 6 & $300(2)$ & $150(2)$ & $75(1)$ & $1.4 \sim 2.00(4)$ \\
\hline 7 & $300(2)$ & $225(3)$ & $300(4)$ & $0.25 \sim 0.425$ \\
\hline 8 & $300(2)$ & $300(4)$ & $225(3)$ & $0.425 \sim 1.0(2)$ \\
\hline 9 & $450(3)$ & $75(1)$ & $225(3)$ & $1.4 \sim 2.00(4)$ \\
\hline 10 & $450(3)$ & $150(2)$ & $300(4)$ & $1.0 \sim 1.4(3)$ \\
\hline 11 & $450(3)$ & $225(3)$ & $75(1)$ & $0.425 \sim 1.0(2)$ \\
\hline 12 & $450(3)$ & $300(4)$ & $150(2)$ & $0.25 \sim 0.425$ \\
\hline 13 & $600(4)$ & $75(1)$ & $300(4)$ & $0.425 \sim 1.0(2)$ \\
\hline 14 & $600(4)$ & $150(2)$ & $225(3)$ & $0.25 \sim 0.425$ \\
\hline 15 & $600(4)$ & $225(3)$ & $150(2)$ & $1.4 \sim 2.00(4)$ \\
\hline 16 & $600(4)$ & $300(4)$ & $75(1)$ & $1.0 \sim 1.4(3)$ \\
\hline
\end{tabular}

TABLE 2 Sand grain sizes used in the tests.

\begin{tabular}{lcccccc}
\hline Sand & I & II & III & IV & V & VI \\
\hline $\begin{array}{l}\text { Diameter } \\
(\mathrm{mm})\end{array}$ & $>2.00$ & $1.40 \sim 2.00$ & $1.00 \sim 1.40$ & $0.43 \sim 1.0$ & $0.25 \sim 0.43$ & $<0.25$ \\
\hline
\end{tabular}

orthogonal array (Table 1) (Taguchi 1990). In Table 1, the values between brackets indicate the factor level.

\section{PROPERTIES OF THE SAND}

All of the tests were carried out with sand from the Baishazhou sand yard in Wuhan City, P.R. China. The dry sand was sieved through five screens, resulting in three coarse sands (II, III, IV) and one medium sand (V), which were used in the tests (Table 2). The densities of sands II, III, IV, and $\mathrm{V}$ are $1.69 \mathrm{~g} / \mathrm{cm}^{3}, 1.68 \mathrm{~g} / \mathrm{cm}^{3}, 1.68 \mathrm{~g} / \mathrm{cm}^{3}$, and $1.63 \mathrm{~g} / \mathrm{cm}^{3}$, respectively, with a relative density $D_{r}$ of $85 \%$. The weights of sand for each $25 \mathrm{~mm}$ under $D_{r}=85$ were calculated and the relative density was controlled by filling and compacting the sand until it reached $25 \mathrm{~mm}$.

A series of tests were conducted using the "PMY-II" plane-strain compression testing machine in The Yangtze River Academy of Sciences of China (Rui et al. 2015). The test sample was placed in a large steel cylinder, as shown in Fig. 3. $\sigma_{1}$ is applied with the loading plate and $\sigma_{3}$ by water pressure through the membrane, allowing them to be independently controlled. The displacement in the direction of $\sigma_{2}$ is prevented by two plates. The size of the sand samples was so large and the size ratio of $d_{\max }$ and the sample width so small (1/150) that a much smaller side effects was expected. Table 3 lists the geomechanical

FIG. 3 Plane-strain testing sample of PMY-II.

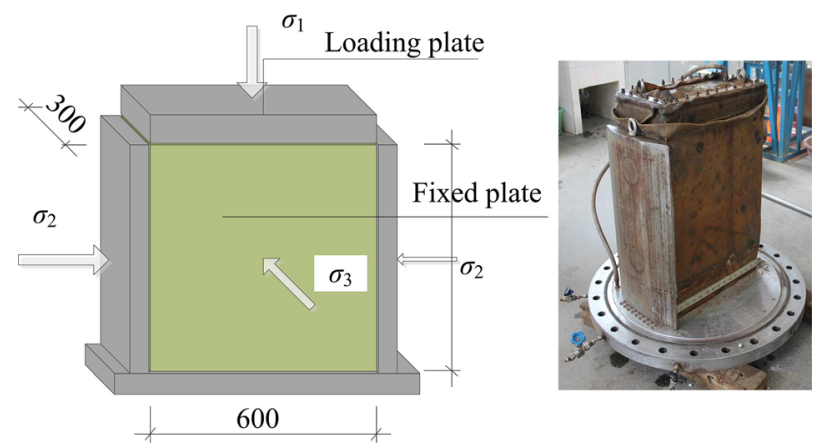

TABLE 3 Friction angles in different tests. ${ }^{a}$

\begin{tabular}{|c|c|c|c|c|c|c|c|c|c|}
\hline \multirow[b]{2}{*}{ Sample } & \multicolumn{3}{|c|}{$\sigma_{3}=100 \mathrm{kPa}\left({ }^{\circ}\right)$} & \multicolumn{3}{|c|}{$\sigma_{3}=200 \mathrm{kPa}\left({ }^{\circ}\right)$} & \multicolumn{3}{|c|}{$\sigma_{3}=400 \mathrm{kPa}\left({ }^{\circ}\right)$} \\
\hline & $\phi_{p}$ & $\psi_{m}$ & $\phi_{r}$ & $\phi_{p}$ & $\psi_{m}$ & $\phi_{r}$ & $\phi_{p}$ & $\psi_{m}$ & $\phi_{r}$ \\
\hline II, $D_{r}=85 \%$ & 51.7 & 15.9 & 44.7 & 48.2 & 13.9 & 42.0 & 45.7 & 10.3 & 41.0 \\
\hline $\mathrm{IV}, D_{r}=85 \%$ & 50.5 & 15.9 & 44.4 & 48.1 & 12.9 & 42.0 & 45.7 & 12.0 & 40.3 \\
\hline $\mathrm{V}, D_{r}=85 \%$ & 49.8 & 15.1 & 44.9 & 48.9 & 11.2 & 42.7 & 45.2 & 8.2 & 41.8 \\
\hline
\end{tabular}

${ }^{\mathrm{a}}$ See Rui et al. (2015). 
FIG. 4 The arrangement of beams and soil pressure cells in tests 1 to 16; the black dots represent the 11 soil pressure cells (each with a number from 1 to 11).

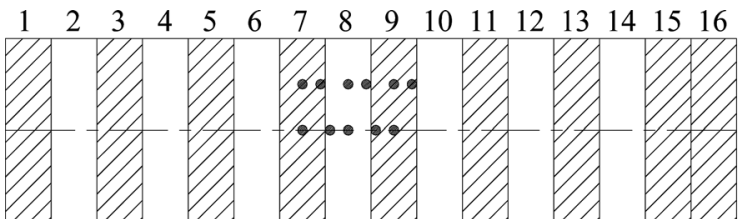

Test No. 1

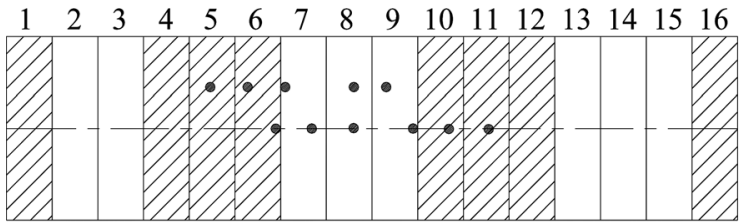

Test No. 3

$\begin{array}{llllllllllllllll}1 & 2 & 3 & 4 & 5 & 6 & 7 & 8 & 9 & 10 & 11 & 12 & 13 & 14 & 15 & 16\end{array}$

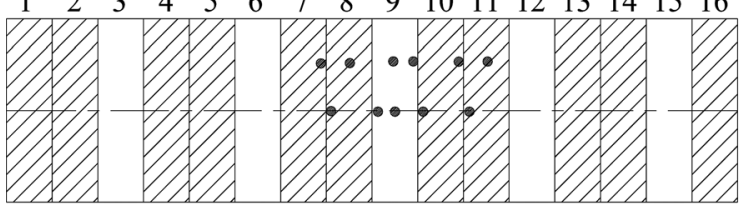

Test No. 5

$\begin{array}{llllllllllllllll}1 & 2 & 3 & 4 & 5 & 6 & 7 & 8 & 9 & 10 & 11 & 12 & 13 & 14 & 15 & 16\end{array}$

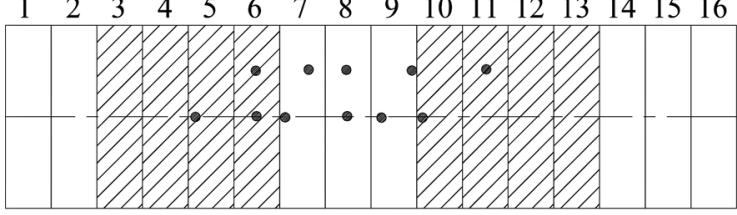

Test No. 7

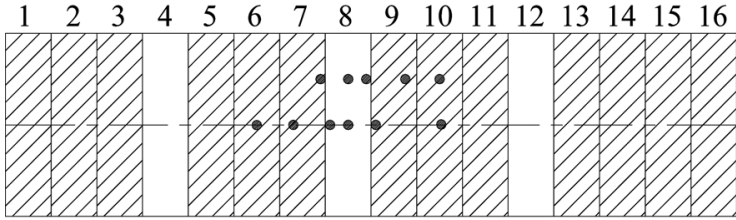

Test No. 9

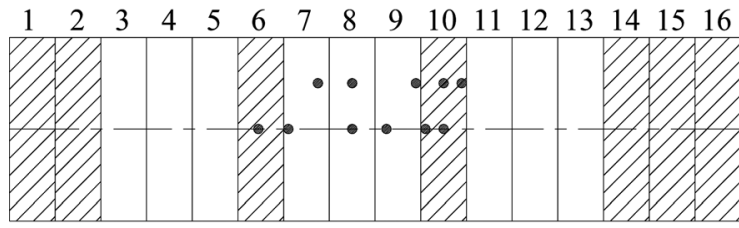

Test No. 11

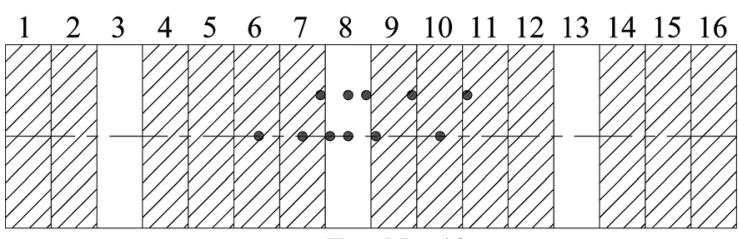

Test No. 13

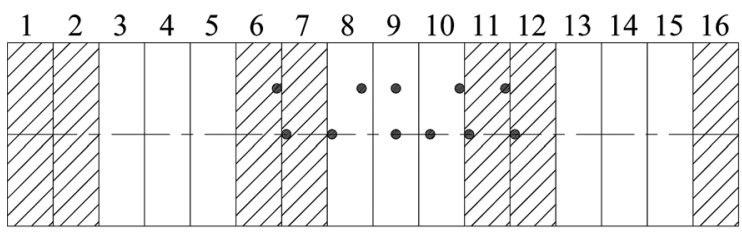

Test No. 15

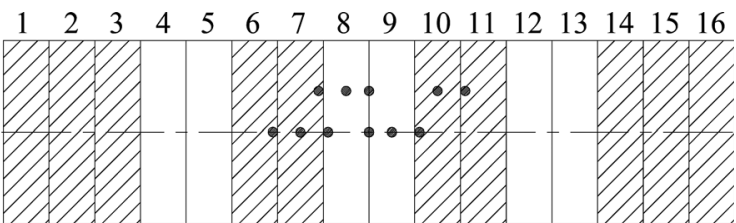

Test No. 2

$\begin{array}{llllllllllllllll}1 & 2 & 3 & 4 & 5 & 6 & 7 & 8 & 9 & 10 & 11 & 12 & 13 & 14 & 15 & 16\end{array}$

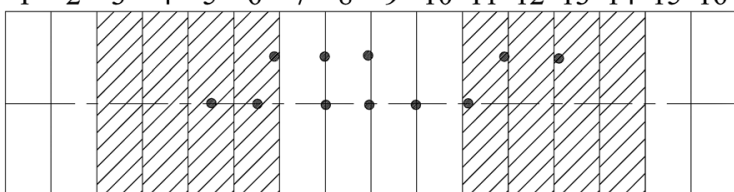

Test No. 4

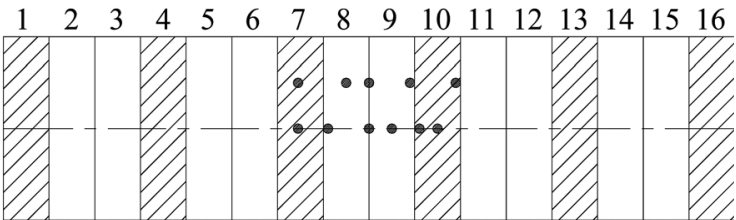

Test No. 6

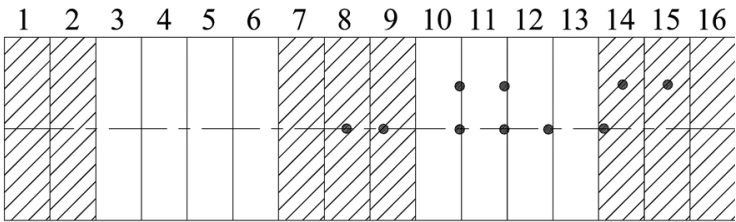

Test No. 8

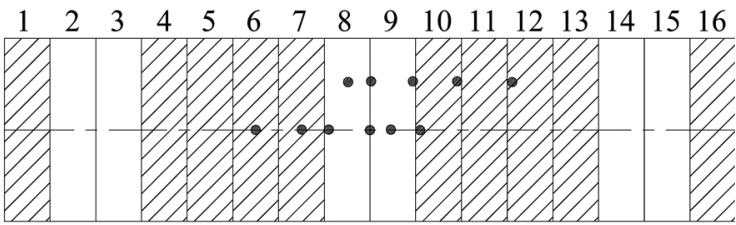

Test No. 10

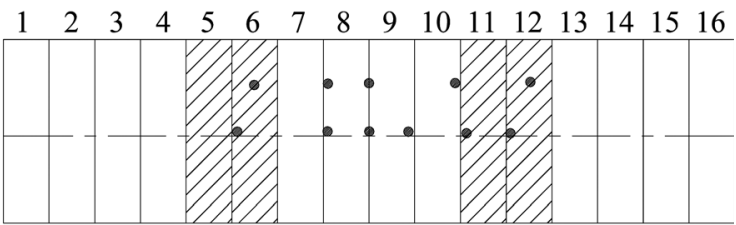

Test No. 12

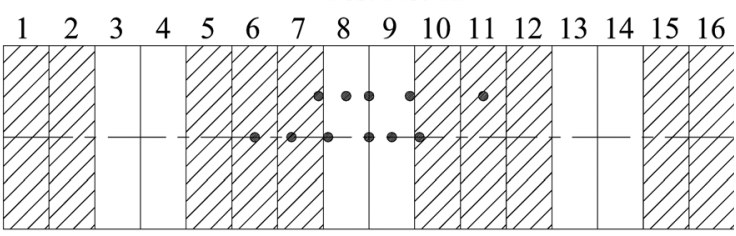

Test No. 14

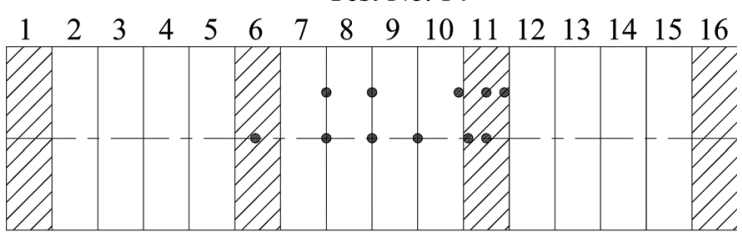

Test No. 16

Copyright by ASTM Int'l (all rights reserved); Tue May 17 03:15:12 EDT 2016 
properties of the sand that were determined using plane-strain (biaxial) tests as described by Rui et al. (2015). Table 3 shows that there were no significant differences of strength between the different sands.

\section{MEASUREMENTS}

Miniature soil pressure cells were used in the experiments. The cells are diaphragm strain-gauged type with self-temperature compensation. The contact area of soil pressure cells is $\varnothing 28 \mathrm{~mm}$ and the thickness of the membrane is $0.28 \mathrm{~mm}$. The measuring range is $0 \sim 50 \mathrm{kPa}$ with a resolution of $0.03 \mathrm{kPa}$. Soil pressure cells were installed in a uniform pattern in one testing unit, as shown in Fig. 4. The arrangement of the movable and fixed beams in each test, with the shaded beams representing the fixed beams (piles); the white beams representing the movable beams (soil between the piles) can also be seen.

During the settling, the beams were moved downward $0.2 \mathrm{~mm}$ each time. The overall displacement of the fill was measured using the PIV technique. A 50-mm fixed focal length lens, which has small lens distortion, was used on the SLR camera used in the test. The images were calibrated to remove noncoplanarity and rescaled by four marks (White et al. 2003).

\section{CALIBRATIONS OF THE PRESSURE CELLS}

An accurate calibration coefficient is obtained by calibrating the pressure cells using sand with the same density as the sand used in the tests (Weiler and Kulhawy 1982). In the first phase of the model tests, the cell pressure increased because of the fill installation. This resulted in a maximum pressure corresponding to the final fill heights of $150,300,450$, or $600 \mathrm{~mm}$. In the second phase, the pressure on the movable beams decreased during movement of the beams, whereas the pressure on the piles increased because of arching. The unloading curves of the cells on the movable beams may depend on the initial maximum pressure, which is related to the fill weight. To account for this, the calibration of the pressure cells was carried out for one loading and four unloading tests.

The calibration tests were conducted using the same sand chamber used in the model tests. In the model tests, a thin layer of sand $\mathrm{V}$ was placed on top of the cells to eliminate the differences among different grains sizes. Similarly, a 30-mm-thick layer of sand $\mathrm{V}$ was used in the calibration tests. The side walls were smeared with silicone oil and covered with two layers of TFE-fluorocarbon sheets with powdered graphite in between to reduce friction along the box walls. The load was applied on the pressure cells through a 30-mm-thick layer of sand V covered by a polymer rubber (EPDM) cushion $(50 \mathrm{~mm})$, a TFEfluorocarbon sheet, and a loading plate. The load consisted of steel bricks in combination with an oil jack system. Fig. 5 shows the measured microstrains for two of the 11 cells.

The loading curves in Fig. 5 show the linear relationship between the applied pressure and measured microstrain. The loading calibration coefficient was determined by fitting a linear formula to the measurements in the loading test. However, the unloading curves show hysteresis similar to that reported by Zhu et al. (2009) and Talesnick (2005). Zhu et al. (2009) normalized the unloading data and suggested double exponential functions for the normalized data. For the present paper, a single exponential function was adopted to fit the normalized data to the unloading calibration tests results:

$$
\sigma / \sigma_{\max }=y_{0}+A \cdot e^{\left(M / M_{\max }-x_{0}\right) / t}
$$

Following Zhu et al. (2009), $\sigma$ and $\sigma_{\max }$ are the current and maximum prior stress, $M$ and $M_{\max }$ are the microstrains corresponding to $\sigma$ and $\sigma_{\max }$, respectively. Coefficients $y_{0}, A, x_{0}$, and $t$ are the unloading calibration coefficients obtained by fitting Eq 1 to the unloading curves of the 11 cells. When fit to Eq 1, the data has a deviation smaller than $0.32 \mathrm{kPa}$ and $7.5 \%$ of the measured microstrains. Fig. 5 shows the normalized measurements and resulting fitting curves of two of the 11 cells. The fitting curves tend to be straight with decreasing fill height, and the unloading tests $(150 \mathrm{~mm})$ were much closer to straight lines. The obtained calibration coefficients are used for the duration of this paper.

\section{Development Patterns of the Slip Surfaces}

\section{SHAPE OF THE SLIP SURFACES}

Many slip surfaces can be identified in the tests, especially after a large movement of the beams. Small displacements that cannot be distinguished with the naked eye are visualized using the PIV technique. The slip surfaces were identified using the areas where the contour lines concentrate. In all of the tests, symmetrical triangular slip surfaces were the first to form as the beams were moved downward. Van der Peet and Van Eekelen (2014) identified this phenomenon numerically in cases with relatively low settlement. With increasing differential settlement, a series of symmetrical slip surfaces formed. The shapes and development processes of the slip surfaces followed three different development patterns: the tower-shaped development pattern, the triangular expanding pattern, and the equal settlement pattern. The three patterns are shown in Fig. 6.

\section{Tower-Shaped Development Pattern}

This pattern occurs in the cases of $H /(s-a) \geq 2$ and $(s-a) / a \leq 2$. This development pattern is typical for test 14 , as shown in Fig. 7. It can be seen from Fig. 7 that a number of triangular slip surfaces form first when the settlement $\Delta$ reaches $4 \mathrm{~mm}$, and then the angle of the slip surfaces increases slightly until $\Delta$ reaches $10 \mathrm{~mm}$. When $\Delta$ exceeds $10 \mathrm{~mm}$, a tower-shaped settlement area develops in the fill and the top of the tower-shaped 
FIG. 5

Calibration measurements and normalized unloading measurements: (a) cell 1 and (b) cell 7. UL, unloading test.
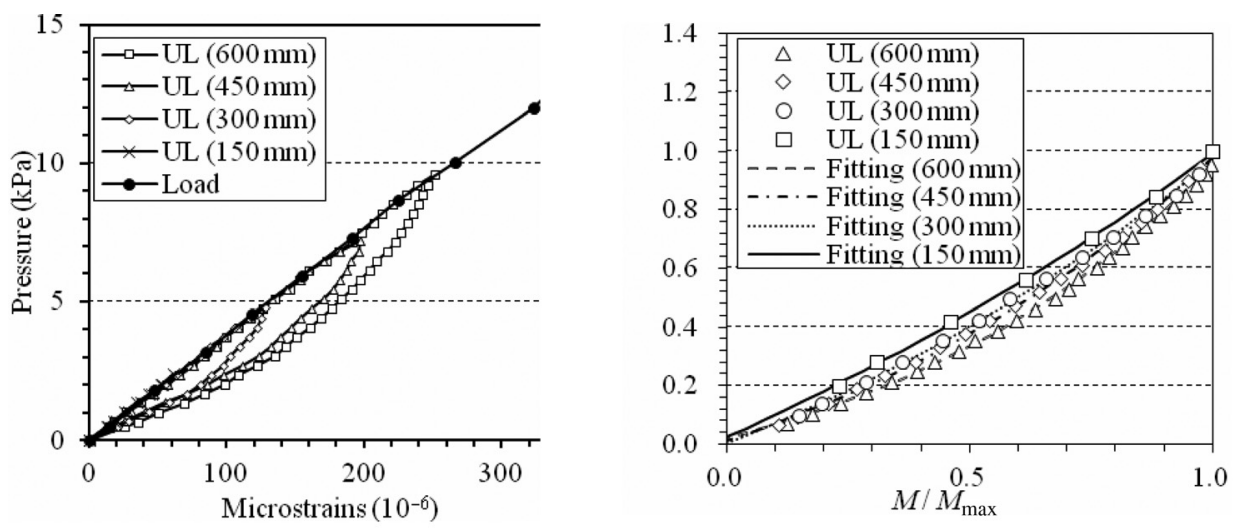

(a) cell $1 \#$
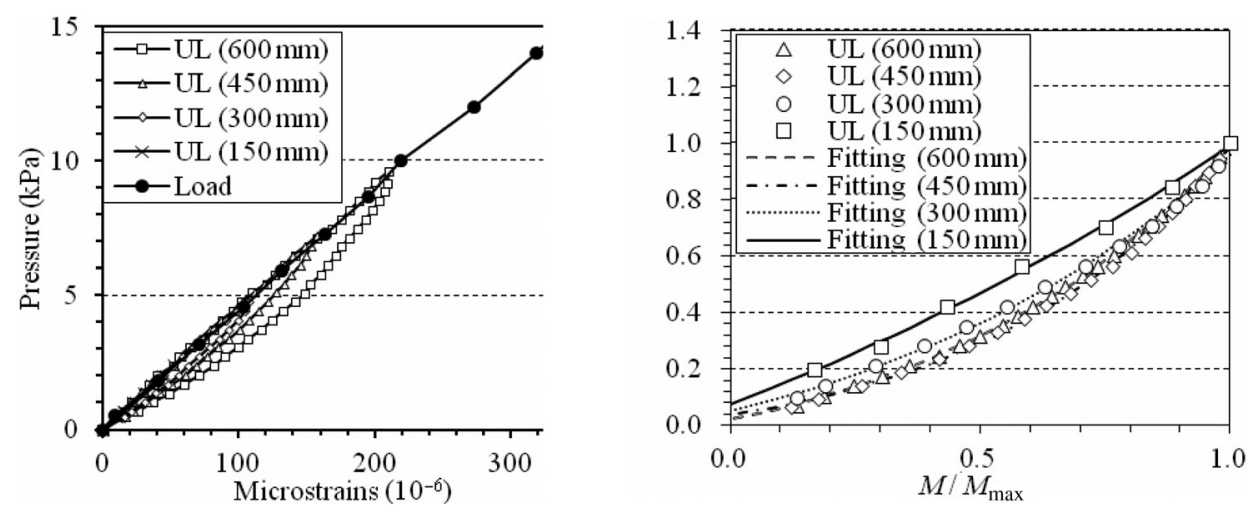

(b) cell 7\#

The ratio of fill height $H$ and trapdoor width $(s-a)$ in Iglesia et al. (2013) is very close to the tests with the tower-shaped development pattern in this paper. The second (triangular arch) and third development stage (a prismatic sliding mass with surface increases with settlement. Finally, vertical slip surfaces develop before $60 \mathrm{~mm}$ displacement. This behavior is found in tests $1,5,6,9,10,13,14$, and 15 . Typical slip surfaces are indicated on the final photos in each test (Fig. 8).

FIG. 6 Three soil-arching evolution patterns for unreinforced piled embankments: (a) tower-shaped development pattern, (b) triangular expanding pattern, and (c) equal settlement pattern.

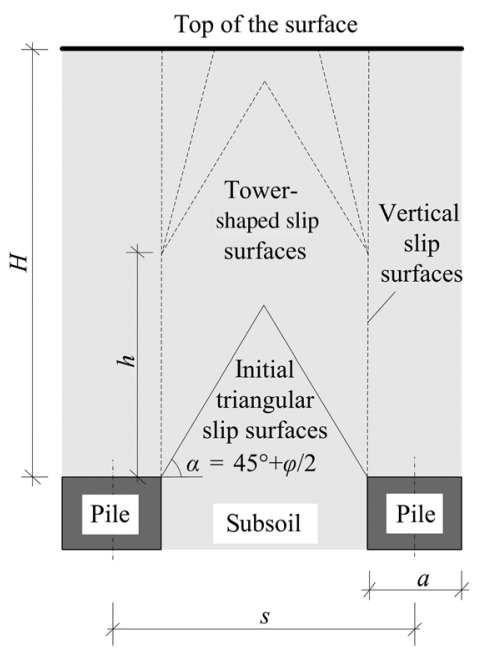

(a)

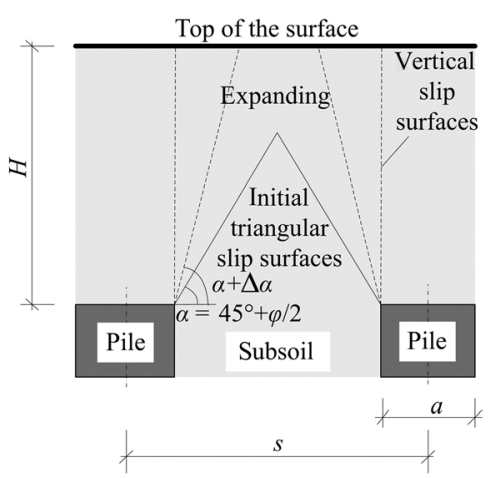

(b)

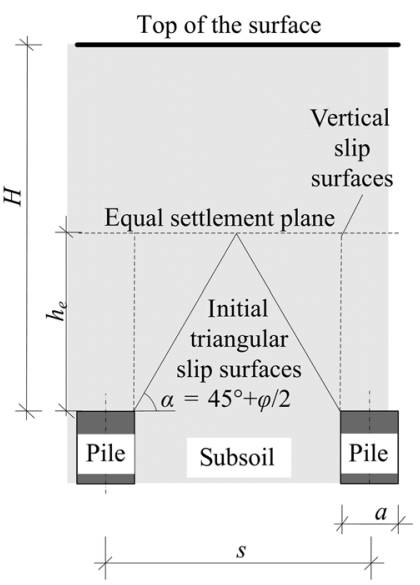

(c) 
FIG. 7 Typical displacement contour plots for the tower-shaped development pattern (test 14).

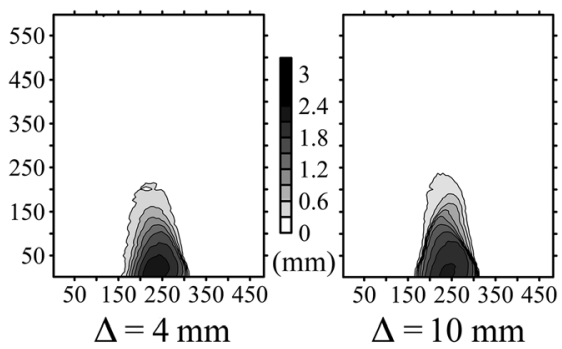

Triangular slip surfaces
Expansi

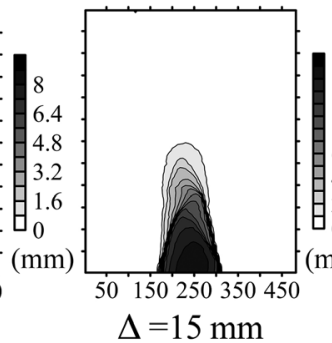

Tower-shaped surfaces

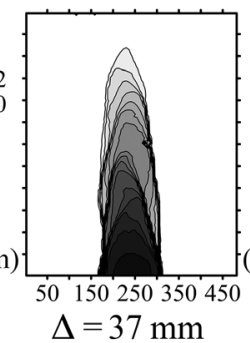

Rising

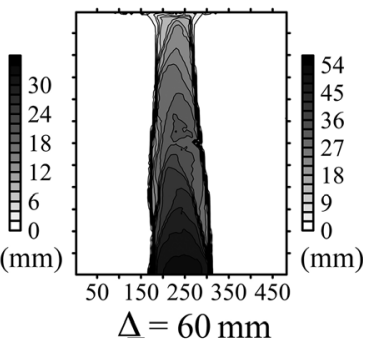

Vertical surfaces vertical sides) described by Iglesia et al. (2013) corresponds well with our observations as shown in Fig. 7. Their initial stage, described as initially curved configuration, was identified in our experiments but did not appear to be a stable physical arch, as it disappears with a very small settlement increase.

\section{Triangular Expanding Pattern}

As in the expansion of triangular slip surfaces, when $H /(s-a) \leq 1.5$ and $(s-a) / a \leq 2$, there is not enough height for the formation of tower-shaped slip surfaces and vertical slip surfaces occur. Typical displacement contours from test 12 can be

FIG. 8 Tower-shaped development pattern.

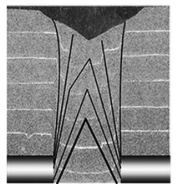

Test 1

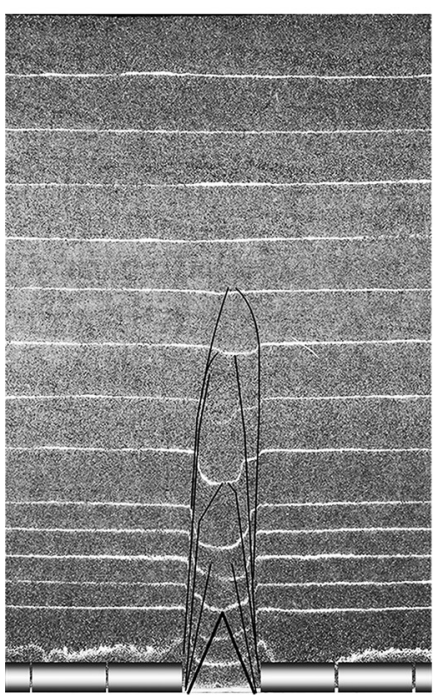

Test 13

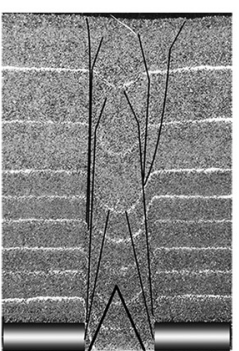

Test 5

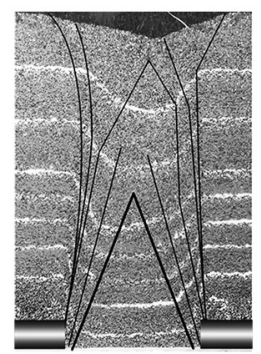

Test 6

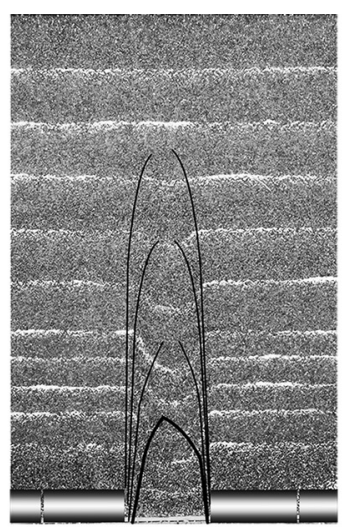

Test 9

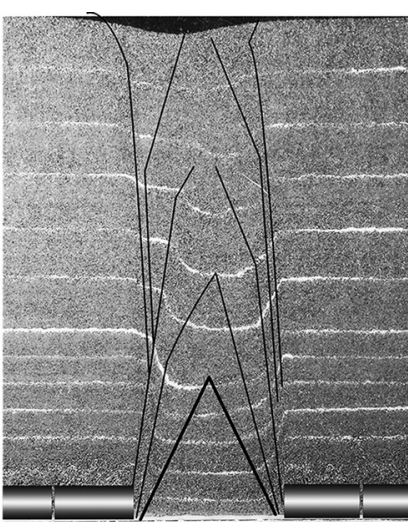

Test 10

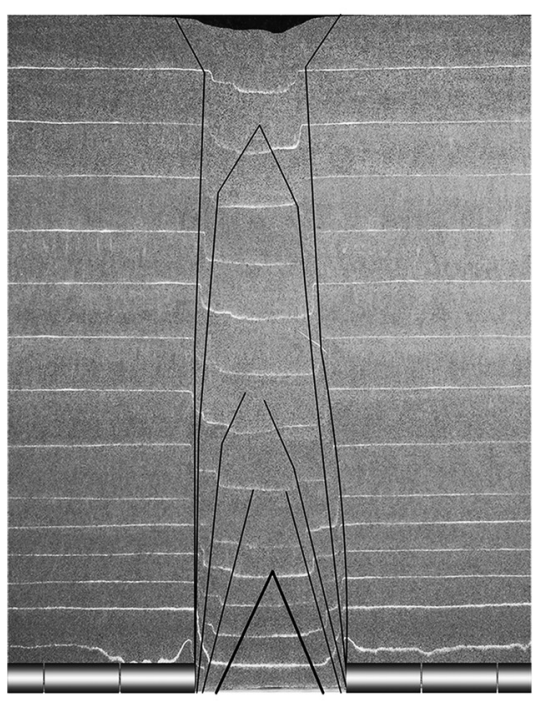

Test 14

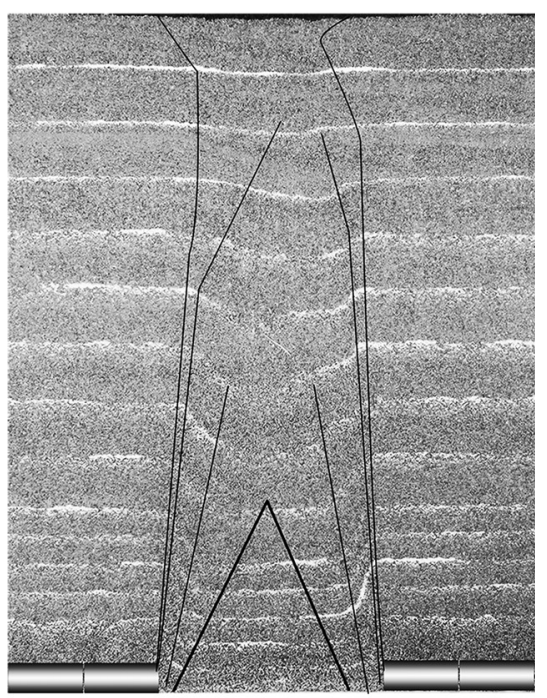

Test 15 
FIG. 9 Typical displacement contour for the triangular expanding pattern (test 12).

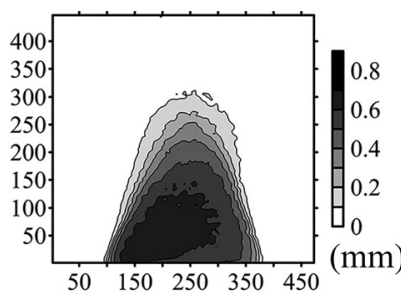

$\Delta=1 \mathrm{~mm}$

Triangular slip surfaces

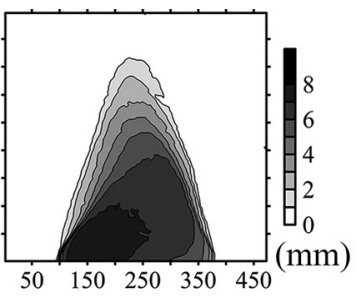

$\Delta=10 \mathrm{~mm}$

Expansion of the surfaces

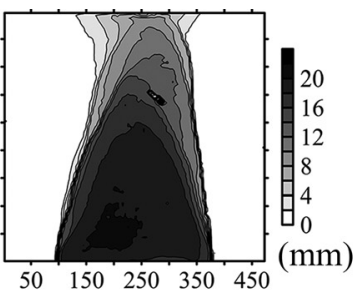

$\Delta=23 \mathrm{~mm}$

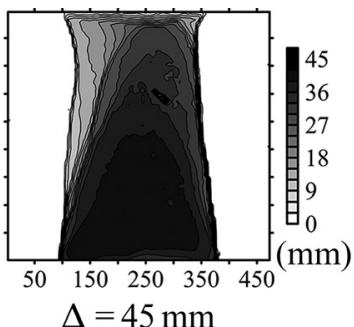

Vertical surfaces seen in Fig. 9. The triangular slip surfaces expand and the inclination increases until vertical surfaces are formed. In most cases, the slip-surface expansions do not occur consecutively and follow an intermittent pattern. The slip surface expansion process of the triangular expanding pattern was described as the triangular expansion zone in Chevalier et al. (2012).

As shown in Fig. 10, tests 2, 3, 4, 7, 8, and 12 follow this intermittent expansion pattern. The slip surfaces can be identified easily by the concentration of the contour lines, which split the area up into several parts. The zones of sand with the same color move synchronously.

\section{Equal Settlement Pattern}

As in tests 11 and 16, in the case of $(s-a) / a \geq 3$ vertical surfaces will form immediately after the triangular slip surfaces. Unlike the other cases described, the sand between the two vertical slip surfaces and above the triangular surfaces will settle synchronously and uniformly with the movement of the beams. Typical displacement contours from test 16 are shown in Fig. 11. Tests
11 and 16 follow this pattern, as can be seen in Fig. 12. The section size of test no. 7 in Chen et al. (2008) is just twice the size of test 16 in this paper, and the equal settlement pattern can also be seen in the deformed embankment pictures.

\section{STRESS-DISTRIBUTION BEHAVIOR FOR THE THREE PATTERNS}

Stress-distribution ratio indicates the concentration of stress on the piles caused by soil arching. The test results were analyzed using the stress-distribution ratio in accordance with Hewlett and Randolph (1988):

$$
n=\frac{\bar{\sigma}_{\text {pile }}}{\bar{\sigma}_{\text {soil }}}
$$

where:

$n=$ the stress-distribution ratio,

$\bar{\sigma}_{\text {pile }}=$ the average soil pressure of the cells on piles, and

$\bar{\sigma}_{\text {soil }}=$ the average soil pressure of the cells in the sand between the piles.

If $n=1.0$, no arching occurs.

FIG. 10 Triangular expanding pattern.

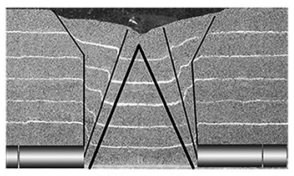

Test 2

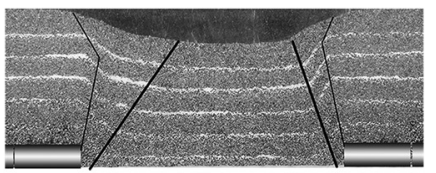

Test 3

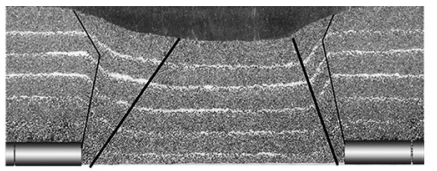

Test 4

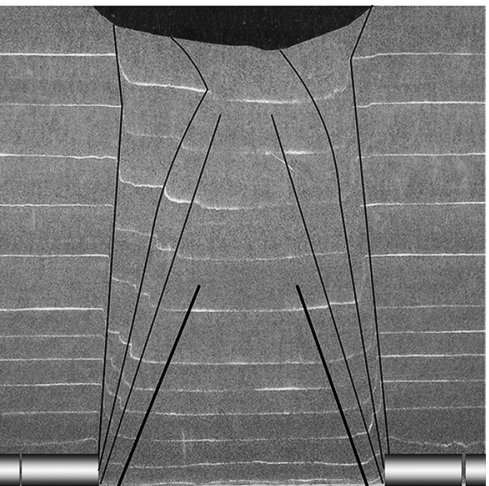

Test 12

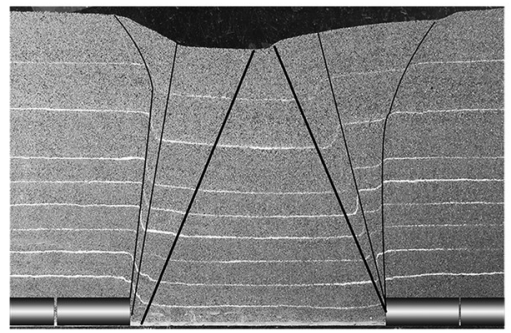

Test 8 
FIG. 11 Typical displacement contour of equal settlement pattern (test 16).

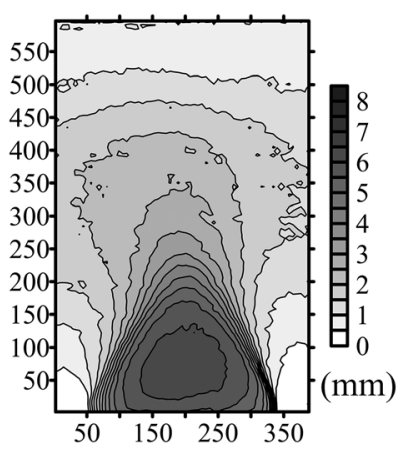

$\Delta=8 \mathrm{~mm}$

Triangular slip surfaces

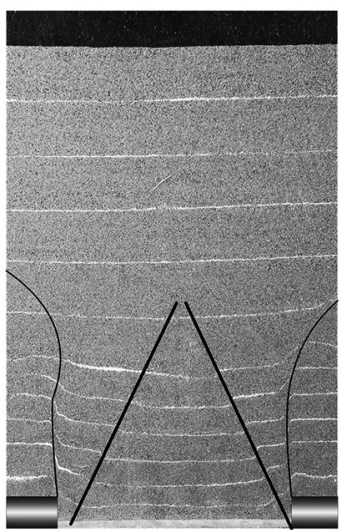

Test 11

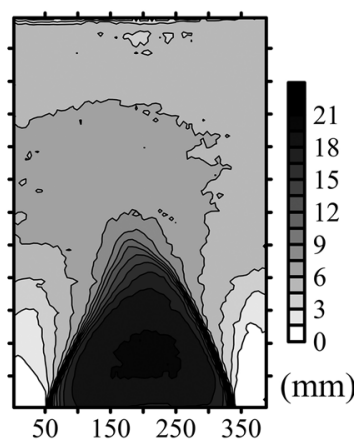

$\Delta=23 \mathrm{~mm}$

FIG. 12 Equal settlement pattern.

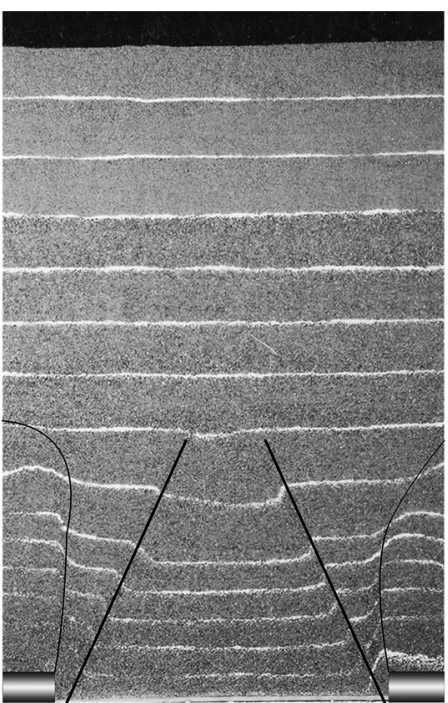

Test 16

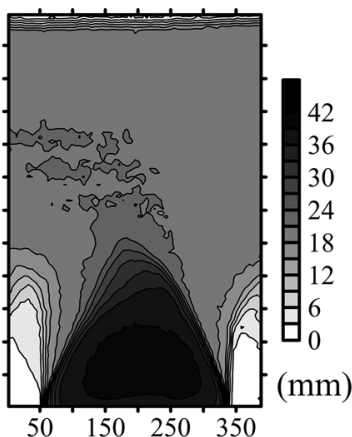

$\Delta=45 \mathrm{~mm}$

Vertical slip surfaces

The stress-distribution ratio can be calculated by the average pressure of the cells on the beams. The pressures of the cells during placement of sand fill and the consequent settlement in test 16 are shown in Fig. 13(a) and 13(b).

Fig. 13(a) shows the relationship between the measured pressures and the fill height during the sand placement. $f$ is considered as the reduction of the self-weight. The initial pressures are linear and deviate a little from the self-weight line with increasing fill height. The final average pressure of the 11 cells is $83 \%$ of the self-weight at a fill height of $600 \mathrm{~mm}$ and $f(17 \%$ of the self-weight) is expected to be carried by the friction.

Fig. 13(b) shows the pressures during settlement. The pressure on the movable beams (soil) decreased dramatically when the movement of beams started, from about $8.0 \mathrm{kPa}$ to a minimum value of $1.2 \mathrm{kPa}$ at a settlement of $6 \mathrm{~mm}$. However, the average pressures of the cells on the piles increased much more slowly to $15.8 \mathrm{kPa}$ at a settlement of $22 \mathrm{~mm}$, and a significant delay of the pressure increase was observed. This implies that a portion of the load was initially taken by friction along the pol$y$ (methyl methacrylate) panels. During the subsequent

FIG. 13

The variations of soil pressure (test 16) for all cells: (a) during the filling and (b) during the settling.

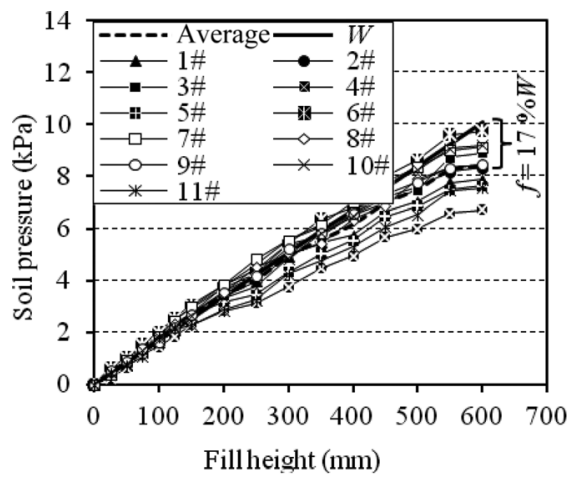

(a)

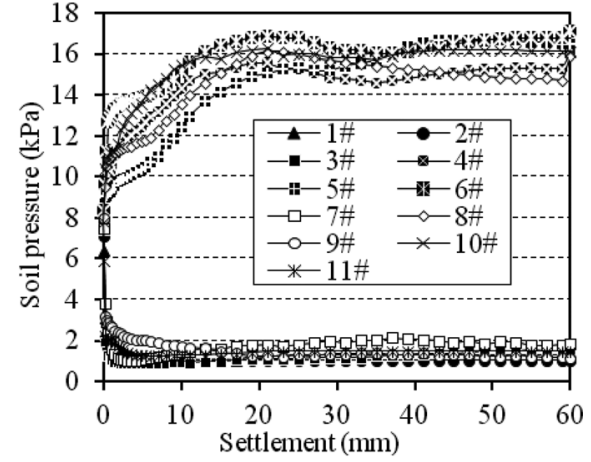

(b) 
movement of the beams, some of the friction was transferred back to the piles and soil. The stress acting on the soil dramatically decreased because of the formation of triangular slip surfaces, and the decreasing stress level caused a significant decrease in the side friction of the triangular region, whose area is much smaller than the total area in most tests. Based on the rigid model family, frictional component acting on movable beams would be much smaller than that acting on the piles. To account for this, we can add $f$ to the load carried by piles and recalculate the stress-distribution ratio $n$ by:

FIG. 14 Stress-distribution ratios in the 16 tests. On the horizontal axes: vertical displacement of the beams ( $\mathrm{mm}$ ); on the vertical axes: stress-distribution ratio $n$ (-). The distance between the curves of $n$ and $n^{\prime}$ indicates the amount of friction; the real stress-distribution ratio should be between $n$ and $n^{\prime}$.

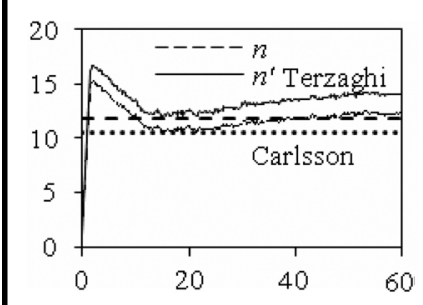

Test 13

$(s-a) / a=0.25 ; H /(s-a)=8$

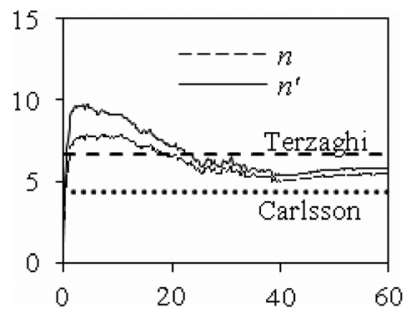

Test 10

$(s-a) / a=0.5 ; H /(s-a)=3$

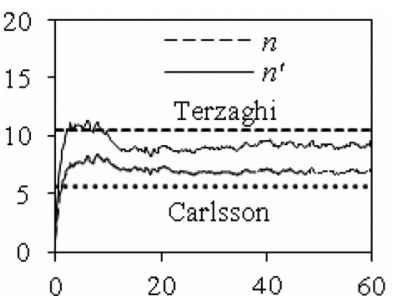

Test 11

$(s-a) / a=3 ; H /(s-a)=2$

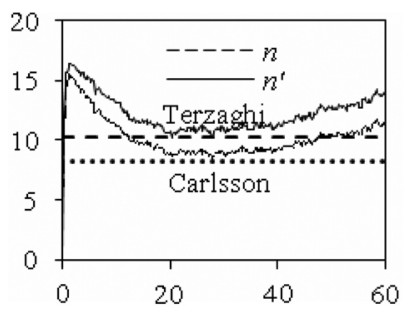

Test 9

$(s-a) / a=0.33 ; H /(s-a)=6$

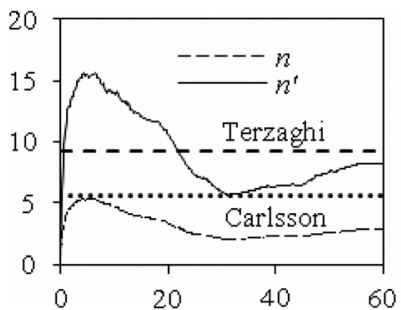

Test 15

$(s-a) / a=1.5 ; H /(s-a)=2.67$

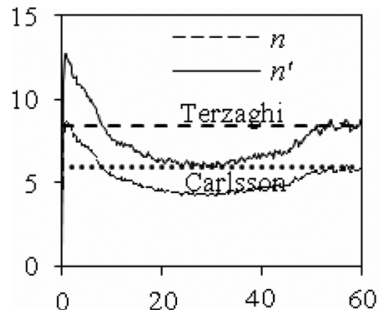

Test 5

$(s-a) / a=0.5 ; H /(s-a)=4$

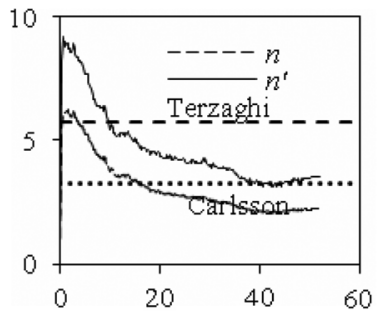

Test 1

$(s-a) / a=1 ; H /(s-a)=2$

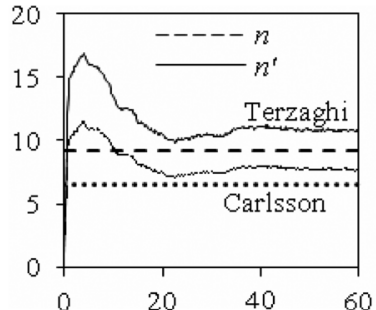

Test 14

$(s-a) / a=0.67 ; H /(s-a)=4$

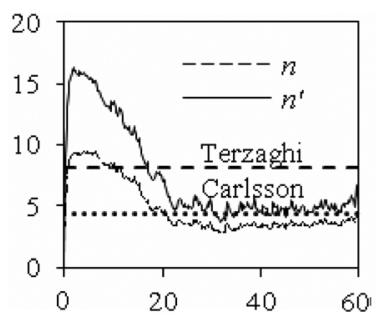

Test 6

$(s-a) / a=2 ; H /(s-a)=2$

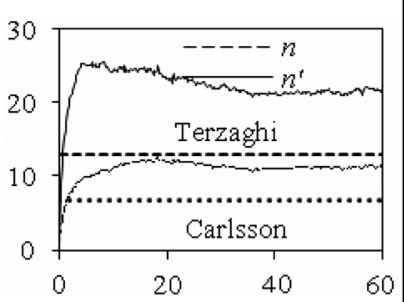

Test 16

$(s-a) / a=4 ; H /(s-a)=2$

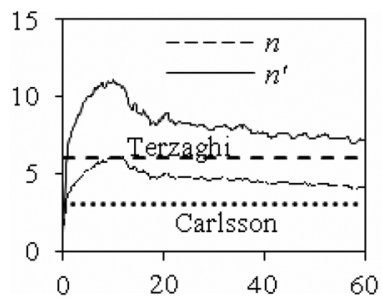

Test 12

$(s-a) / a=2 ; H /(s-a)=1.5$

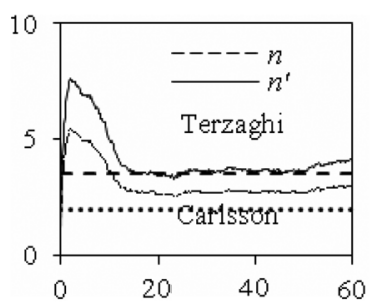

Test 7

$(s-a) / a=0.75 ; H /(s-a)=1.33$

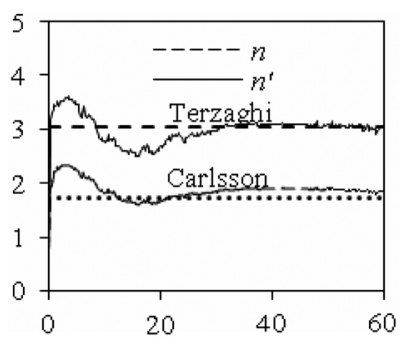

Test 2

$(s-a) / a=1 ; H /(s-a)=1$

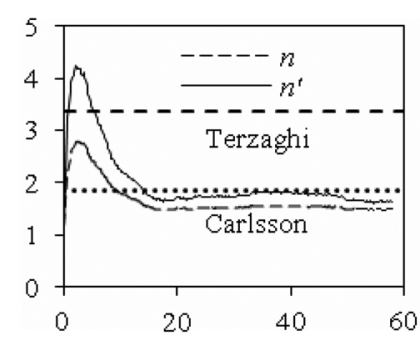

Test 8

$(s-a) / a=1.33 ; H /(s-a)=1$

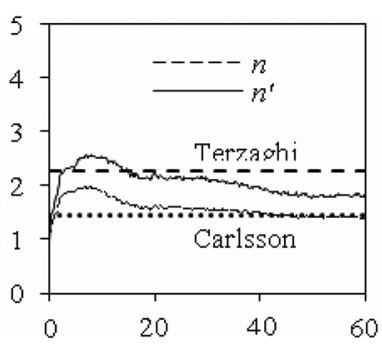

Test 3

$(s-a) / a=1 ; H /(s-a)=0.67$

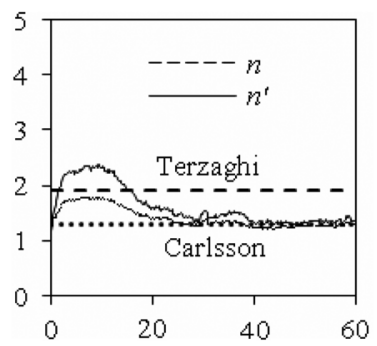

Test 4

$(s-a) / a=1 ; H /(s-a)=0.5$ 


$$
n^{\prime}=\frac{\left(\bar{\sigma}_{\text {pile }} \times a+f\right)}{\bar{\sigma}_{\text {soil }} \times a}
$$

Using Eq 3, $n^{\prime}$ will be overestimated for the frictional component of the load carried by the movable beams. Thus the real stress-distribution ratio falls between $n$ and $n^{\prime}$ and the distance between them indicates the amount of friction in the system.

The curves of the stress-distribution ratios as a function of the settlement of the subsoil are shown in Fig. 14. Despite the frictional component, the shape of the stress-distribution curves does not change. The plots in Fig. $\mathbf{1 4}$ can be classified into three types showing characteristics of the development pattern that it belongs to.

- The first type is found for tests with a relative height $H /(s-a) \geq 2$ and relative trapdoor width $(s-a) / a \leq 2$. This type shows the stress-distribution behavior of the towershaped development pattern. The stress-distribution ratio peaks at a very small displacement and falls rapidly and the residual ratio is quite high. This type of curve was seen in tests $1,5,9,10,13,14$, and 15 .

- With the increase in trapdoor width $(s-a)$, more displacement is needed before reaching the peak stressdistribution value. This is found when $H /(s-a) \leq 1.5$ and $(s-a) / a \leq 2$ and shows the stress-distribution behavior of the triangular expanding pattern. The curve becomes flatter and maintains the peak level during some of the increase in settlement. The residual ratio does not rise; rather, it generally falls to values lower than 2 . This curve was seen in tests $2,3,4$, and 12 .

- If trapdoor width is increased to $(s-a) / a \geq 3$ as in the equal settlement pattern, the curve does not decline much after reaching the peak value, as in tests 11 and 16 .

In Fig. 14, test 6 was classified under the first type of curve and tests 7 and 8 under the second type, although their shapes fall somewhere between the first and the second type of curve.

Terzaghi (1943) established a method based on the equal settlement plane and the vertical shear planes, which are very close to the equal settlement pattern and vertical slip surfaces observed in the model tests. The triangular deformation zone observed in the model tests confirmed the rigid model family. The predictions of Terzaghi's (1943) method and Carlsson's method (1987) are shown in Fig. 14. It can be seen that the predictions of Terzaghi's method are larger than Carlsson's method, although both fall within the range of stressdistribution ratios of the model tests.

\section{INFLUENCES OF THE SIDE WALL FRICTION}

Many geotechnical model tests will be influenced by the side wall friction. Some common measures of reducing the friction, including using a TFE-fluorocarbon membrane and smearing grease on the side walls, are not adaptable for direct visualization of the sand. In most trapdoor tests with transparent panels (Hewlett and Randolph 1988; Chen et al. 2008; Costa et al. 2009), the influence of friction and measures to reduce it are not discussed.

Fig. 13(a) shows that the side wall friction in test 16 develops to a maximum of approximately $17 \%$ with increasing fill height $H$. Fig. 13(b) shows that friction continued to develop during settlement. As $H$ increases, arching effects in the width direction of the sand chamber could develop, which increase the friction and normal force acting on the poly(methyl methacrylate) panels (Fig. 15). The assumption relies on the influence of boundary effects, which are controlled by the relative dimensions $H / w$ according to the measurements, where $w$ is the width of the sand chamber. Chen et al. (2008) chose $H / w=0.42$ to 1.2 in their piled embankment model tests. Costa et al. (2009) adopted the relative dimensions to be 1.5, and Chevalier et al. (2012) adopted $H / w=0.375$ to 2 in their single trapdoor tests. The relative dimension $H / w$ in tests 1 to 12 ranges from 0.5 to 1.5 , and $H / w$ in tests 13 to 16 is 2 . The ratio of $H / w$ of the 16 tests falls within the ranges used in the previous studies.

Because of the different geometrical combinations, the reduction of total load $f$, treated as friction, differs between the tests. The ratio $f / P_{\text {total, }}$ where $P_{\text {total }}$ is the total weight of the sand fill calculated by the average pressure, of each test is listed in Table 4. It is found that:

FIG. 15

The arching effects in the width direction.
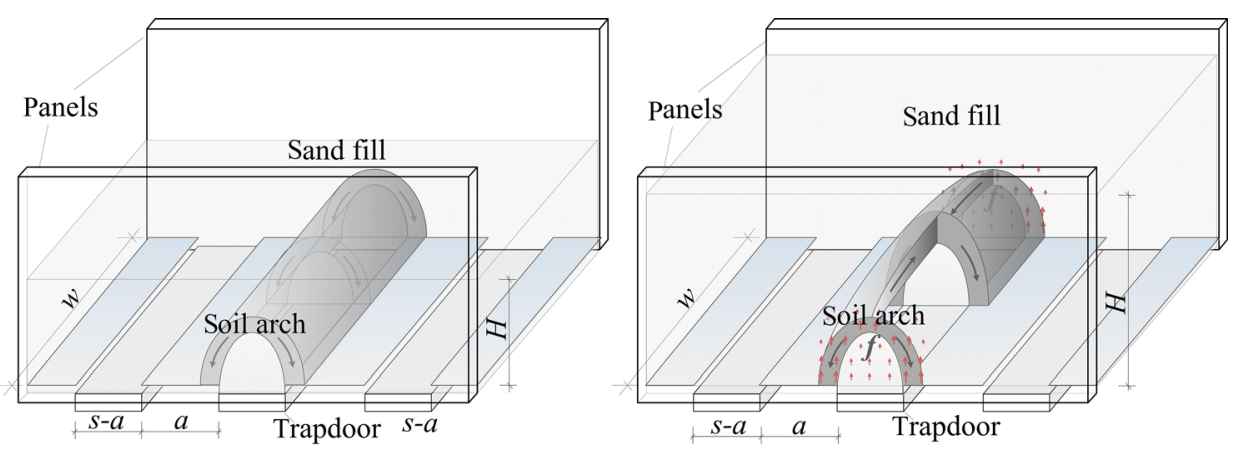
TABLE 4 Relative friction.

\begin{tabular}{lllllc}
\hline Test & $H(\mathrm{~mm})$ & $H /(s-a)$ & $H / w$ & $(s-a) / a$ & $f / P_{\text {total }}(\%)$ \\
\hline 1 & 150 & 2 & 0.5 & 1 & 26 \\
2 & 150 & 1 & 0.5 & 1 & 29 \\
3 & 150 & 0.67 & 0.5 & 1 & 14 \\
4 & 150 & 0.5 & 0.5 & 1 & 3 \\
5 & 300 & 4 & 1 & 0.5 & 27 \\
6 & 300 & 2 & 1 & 2 & 20 \\
7 & 300 & 1.33 & 1 & 0.75 & 21 \\
8 & 300 & 1 & 1 & 1.33 & 7 \\
9 & 450 & 6 & 1.5 & 0.33 & 18 \\
10 & 450 & 3 & 1.5 & 0.5 & 6 \\
11 & 450 & 2 & 1.5 & 3 & 41 \\
12 & 450 & 1.5 & 1.5 & 2 & 33 \\
13 & 600 & 8 & 2 & 0.25 & 13 \\
14 & 600 & 4 & 2 & 0.67 & 27 \\
15 & 600 & 2.67 & 2 & 1.5 & 53 \\
16 & 600 & 2 & 2 & 4 & 41 \\
\hline
\end{tabular}

(1) $f / P_{\text {total }}$ increases with $H / w$. The average $f / P_{\text {total }}$ is $18 \%$, $18.75 \%, 24.5 \%$, and $33.5 \%$ for $H / w=0.5$ (tests 1 to 4 ), 4 (tests 5 to 8 ), 1.5 (tests 9 to 12 ), and 2 (tests 13 to 16 ), respectively. Thus, it can be concluded that using a low $H / w$ ratio can reduce the influence of friction in the model tests.

(2) In tests with a small relative height $H /(s-a)$, the frictional component is small. The friction is only $3 \%$ in test 4 with a relative height of 0.5 .

(3) The decrease of the relative net spacing $(s-a) / a$ can result in a decrease of friction. This drop is because of the decreasing movement disturbance because of a narrow trapdoor.

According to Table 4, the friction in tests 3, 4, 8, 10, and 13 is less than $15 \%$ of the total fill weight. Tests 10 and 13 belong to the tower-shaped development pattern, whereas tests 3,4 , and 8 show the triangular development pattern. The influence of friction in these five tests is limited. The friction in tests $1,2,5,6,7,9$ and 14 is within $30 \%$ of each other, and these seven tests show the triangular development pattern or the tower-shaped development pattern. Because of the influences of friction in these tests, the soil-arching development patterns were studied rather than a quantitative assessment. The existence of the towershaped and triangular development patterns was confirmed through these tests.

For the equal settlement pattern of tests 11 and 16, both of the frictions are $41 \%$ of the total fill weight. This is a pattern with a movement of the entire sand fill. It is clear that the side wall friction helps to restrict the displacement of the sand so that the settlement might be even larger or appear earlier without the influence of the friction. As in test no. 7 with $\mathrm{H} / \mathrm{w}$ of 0.6 in Chen et al. (2008), the deformation exhibits equal settlement behavior. These confirm the possibility of the equal settlement-development pattern.

\section{Discussions}

\section{INITIAL TRIANGULAR SLIP SURFACES}

The angles of the initial triangles are within $2^{\circ}$ between tests. The average initial triangle angle of the tower-shaped development pattern, triangular expanding pattern, and equal settlement pattern are $66^{\circ}, 66^{\circ}$, and $65^{\circ}$, respectively.

Terzaghi (1943) suggested that the inclination of the slip surface decreases from $90^{\circ}$ to $45^{\circ}+\varphi / 2$ with increasing $H /(s-a)$, and the slip surfaces follow the active fracture plane when the values for $H$ are relatively high. Most of the initial slip surfaces in the tests occur when movement is less than $3 \mathrm{~mm}$. The trapdoor tests done by Terzaghi are similar to the tests described here. The initial triangular slip surfaces in the tests with low $H /(s-a)$ are barely detectable with the naked eye but can be visualized using the PIV technique, which may be why Terzaghi chose the vertical slip surfaces that finally occurred to develop his method.

The stress levels of the model tests were less than or close to the minimum confining stress $\sigma_{3}=100 \mathrm{kPa}$ used in the plane strain compression tests. Because of the stress-dependent dilatancy of the sand, the friction angles obtained under $\sigma_{3}=100 \mathrm{kPa}$ are closest to the model tests among the three different confining stresses in Table 3. In the case of $\sigma_{3}=100 \mathrm{kPa}$, the average peak friction angle for a relative density of $85 \%$ is about $51^{\circ}$ and the average residual angle is about $45^{\circ}$. The angle of the related active fracture plane will be $45^{\circ}+\varphi / 2=70.5^{\circ}$ using the peak friction angle. If a residual angle of $45^{\circ}$ is introduced, the active fracture plane angle will be $67.5^{\circ}$ and is much closer to the tests results.

Triangular slip surfaces occur at small settlements and are very close to the peak values of the stress-distribution ratio. Accordingly, the initial triangular slip surfaces are assumed to be closely related to the peak value of the stress-distribution ratio. It can also be concluded that the formation of the vertical surface is closely related to the residual stress-distribution ratio.

\section{SHAPE OF THE SLIP SURFACES}

Slip surfaces, especially the initial triangular slip surfaces, are usually straight planes. The initial triangular slip surfaces are assumed to approximate active fracture planes, which appear linear because the stress state along the surfaces is almost uniform with the maximum principle stress before failure in the vertical direction. These slip surfaces could occur when there is no arching in the sand between the beams (e.g., no friction at the interface of the beam and sand fill), and there will be no rotation of the principal stress (see Fig. 16(a)).

However, arch-like slip surfaces can also be found in test 9 and test 13 (Fig. 8). These tests have a relatively high fill of 


\section{FIG. 16}

Straight and arched slip surfaces in a piled embankment.

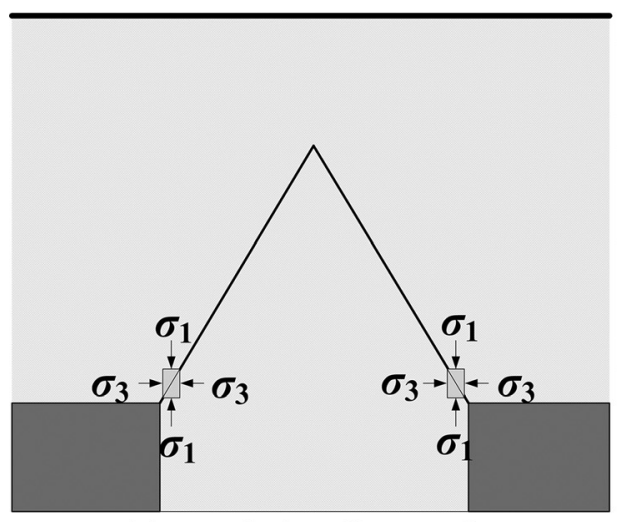

(a) straight slip surface

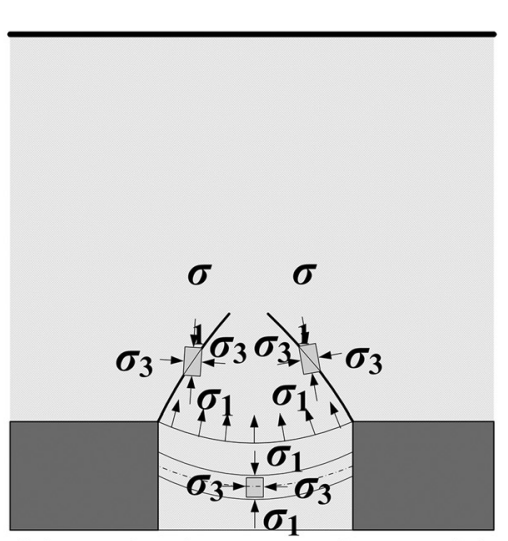

(b) arch-shape surface with narrow spacing
$450 \mathrm{~mm}$ and $600 \mathrm{~mm}$ and the smallest trapdoor width of $75 \mathrm{~mm}$ when compared to the other tests. A minor principal stress arch between the beams (piles), given by Handy (1985), could explain the formation of arch-like slip surfaces (see Fig. 16(b)), which will support the fill and cause a rotation of the principal stress. This leads to an increase in soil arching.

\section{Conclusions}

Soil-arching development was studied in a series of 2D multi-trapdoor model tests looking at four factors (fill height, trapdoor width, pile width, and sand grain size), and four values for each factor. An orthogonal array was adopted to arrange the tests. The PIV technique was used to measure the overall displacement, and pressure cells were used to test the stress distribution. Those pressure cells were calibrated under both loading and unloading conditions so as to coincide with the loading modes of the piles and trapdoors. The loading curves of the cells showed linear relationships, whereas the unloading curves showed hysteresis of the measured microstrains, and a single exponential function can be used to fit the unloading curves. The calibration coefficients were then used in the model tests.

Several conclusions were drawn on the basis of the model test results. First, triangular slip surfaces will form after very minor movement of the trapdoors; hence, the term "initial triangular slip surfaces." These initial triangular slip surfaces evolve following three types of patterns. Half of the tests exhibited the tower-shaped development pattern, where the relative height is $H /(s-a) \geq 2$ and the relative trapdoor width is $(s-a) /$ $a \leq 2$. In this pattern, initial triangular slip surfaces evolve into tower-shaped surfaces, which rise with increasing settlement. The triangular expanding pattern occurs when $H /(s-a) \leq 1.5$ and $(s-a) / a \leq 2$. For this pattern, the triangular slip surfaces expand and remain straight lines. Vertical slip surfaces form at the end of these two patterns. In the case of $(s-a) / a \geq 3$, vertical triangular surfaces form immediately after the initial triangular ones. The sand above the vertical slip surfaces and the triangular slip surfaces settles synchronously and uniformly. This development pattern is called the equal settlement pattern. The stress-distribution ratio versus settlement curves also showed three different curve types, which correspond to the three deformation-development patterns. The stress-distribution curve of the tower-shaped development pattern reaches the peak value at a very small displacement then decreases rapidly. The stress-distribution ratio curve of the triangular expanding pattern flattens, whereas the equal settlement pattern curve remains relatively constant after reaching the peak value.

Side wall friction was found in the model tests. It was supposed that the friction increased with the relative dimension $H / w$ because of the arching effects developed in the width direction. The calculated friction showed that a small relative height and a small relative net spacing helped decrease the side wall friction in the model tests.

It was assumed that the initial triangular slip surfaces are active fracture planes with an inclination of $45^{\circ}+\varphi / 2$. The angle calculated by the residual friction angle agreed with the measured angles better than the peak friction angle.

\section{ACKNOWLEDGMENTS}

This study is supported by the National Natural Science Foundation of China (Project No. 51208403) and the Fundamental Research Funds for the Central Universities (WUT: 2013-II018). The writers gratefully acknowledge their support.

\section{References}

BS8006-1, 2010, "Code of Practice for Strengthened/Reinforced Soils and Other Fills," The British Standards Institution, London, p. 250.

Carlsson, B., 1987, Reinforced Soil, Principles for Calculation, Terratema AB, Linköping, Sweden. 
Chen, Y. M., Cao, W. P., and Chen, R. P., 2008, “An Experimental Investigation of Soil Arching Within Basal Reinforced and Unreinforced Piled Embankments," Geotext. Geomembr., Vol. 26, No. 2, pp. 164-174.

Chevalier, B., Briançon, L., Villard, P., and Combe, G., 2010, "Prediction of Load Transfers in Granular Layers Used in Rigid Inclusions Technique-Experimental and Discrete Element Method Analysis," GeoFlorida 2010, Advances in Analysis, Modeling \& Design, West Palm Beach, FL, February 20-24, 2010, Geo-Institute of ASCE, Reston, VA.

Chevalier, B., Combe, G., and Villard, P., 2012, "Experimental and Discrete Element Modeling Studies of the Trapdoor Problem: Influence of the Macro-Mechanical Frictional Parameters," Acta Geotech., Vol. 7, No. 1, pp. 15-39.

Costa, Y. D., Zornberg, J. G., Bueno, B. S., and Costa, C., 2009, "Failure Mechanisms in Sand Over a Deep Active Trapdoor," J. Geotech. Geoenviron. Eng., Vol. 135, No. 11, pp. 1741-1753.

CUR 226, 2010, "Ontwerprichtlijn paalmatrassystemen [Design Guideline Piled Embankments]," Houten, The Netherlands (in Dutch), p. 138.

CUR 226, 2016, "Dutch Design Guideline Piled embankments," revision CUR 226, SBRCURnet and Taylor \& Francis, London, U.K.

DGGT (German Geotechnical Society), 2011, Recommendations for Design and Analysis of Earth Structures Using Geosynthetic Reinforcements-EBGEO, Ernst \& Sohn Berlin, Germany, p. 313.

Eskişar, T., Otani, J., and Hironaka, J., 2012, "Visualization of Soil Arching on Reinforced Embankment With Rigid Pile Foundation Using X-Ray CT," Geotext. Geomembr., Vol. 32, pp. $44-54$.

Guido, V. A., Kneuppel, J. D., and Sweeney, M. A., 1987, "Plate Loading Test on Geogrid Reinforced Earth Slabs," Geosynthetics'87 Conference, New Orleans, LA, February 24-25, 1987, Industrial Fabrics Association International, Saint Paul, MN.

Handy, R. L., 1985, "The Arch in Soil Arching," J. Geotech. Eng., Vol. 111, No. 3, pp. 302-318.

Hewlett, W. J. and Randolph, M. F., 1988, "Analysis of Piled Embankments,” Ground Eng., Vol. 22, No. 3, pp. 12-18.

Iglesia, G. R., Einstein, H. H., and Whitman, R. V., 2013, "Investigation of Soil Arching With Centrifuge Tests," J. Geotech. Geoenviron. Eng., Vol. 140, No. 2, pp. 248-256.

IREX, 2012, "Recommendations for the Design, Construction and Control of Rigid Inclusion Ground Improvements," ASIRI National Project, Presses des Ponts, Paris, France, p. 316.

Kempfert, H.-G., Göbel, C., Alexiew, D., and Heitz, C., 2004, "German Recommendations for Reinforced Embankments on Pile-Similar Elements," Third European Geosynthetic Conference, German Geotechnical Society (DGGT), Munich, Germany, March 1-3, 2004.

Ladanyi, B. and Hoyaux, B., 1969, "A Study of the Trap-Door Problem in a Granular Mass," Can. Geotech. J., Vol. 6, No. 1, pp. 1-14.

Le Hello, B. and Villard, P., 2009, "Embankments Reinforced by Piles and Geosynthetics-Numerical and Experimental Studies Dealing With the Transfer of Load on the Soil Embankment," Eng. Geol., Vol. 106, Nos. 1-2, pp. 78-91.

Meguid, M. A., Saada, O., Nunes, M. A., and Mattar, J., 2008, "Physical Modeling of Tunnels in Soft Ground: A Review," Tunn. Undergr. Sp. Tech, Vol. 23, No. 2, pp. 185-198.
Marston, A. and Anderson, A. O., 1913, "The Theory of Loads on Pipes in Ditches: And Tests of Cement and Clay Drain Tile and Sewer Pipe," Bulletin 31, IA Engineering Experiment Station, Iowa State College, Ames, IA.

Oiseth, E., Svano, G., Watn, A., and Emdal, A., 2002, "A Computer Program for Designing Reinforced Embankments," Seventh International Conference on Geosynthetics, 7-ICG, Nice, France, September 22-27, 2002.

Paikowsky, S. and Tien, H., 2002, "Experimental Examination of the Arching Mechanism on the Micro Level," Third International DEM Conference, Santa Fe, NM, September 23-25, 2002.

Rogbeck, Y., Gustavsson, S., Södergren, I., and Lindquist, D., 1998, "Reinforced Piled Embankments in Sweden-Design Aspects," Sixth International Conference on Geosynthetics, Atlanta, GA, March 25-29, 1998, Industrial Fabrics Association International, Roseville, MN.

Rui, R., Van Tol, A. F., Xia, Y. Y., and Hu, G., 2015, "Large Size Plane Strain Compression Tests on Sands and 2D DEM Calibrations," The XVI European Conference on Soil Mechanics and Geotechnical Engineering, Edinburgh, U.K., September 13-17, 2015, British Geotechnical Association, London, U.K.

Sloan, S. W., Assadi, A., and Purushothaman, N., 1990, "Undrained Stability of a Trapdoor," Geotechnique, Vol. 40, No. 1, pp. 45-62.

Taguchi, G., 1990, Introduction to Quality Engineering, McGraw-Hill, New York, p. 191.

Talesnick, M., 2005, "Measuring Soil Contact Pressure on a Solid Boundary and Quantifying Soil Arching," Geotech. Test. J., Vol. 28, No. 2, pp. 171-179.

Terzaghi, K., 1936, "Stress Distribution in Dry and in Saturated Sand Above a Yielding Trap-Door," Proceedings of the International Conference on Soil Mechanics and Foundation Engineering, Vol. I, pp. 307-311.

Terzaghi, K., 1943, Theoretical Soil Mechanics, Wiley, New York, p. 503.

Van der Peet, T. C. and Van Eekelen, S. J. M., 2014, "3D Numerical Analysis of Basal Reinforced Piled Embankments," Tenth International Conference on Geosynthetics, Berlin, Germany, September 21-25, 2014, German Geotechnical Society (DGGT), Essen, Germany.

Van Eekelen, S. J. M., Bezuijen, A., and Oung, O., 2003, "Arching in Piled Embankments: Experiments and Design Calculations," Proceedings of Foundations: Innovations, Observations, Design and Practice, Dundee, Scotland, September 2-5, 2003.

Van Eekelen, S. J. M., Bezuijen, A., and Van Tol, A. F., 2011, "Analysis and Modification of the British Standard BS8006 for the Design of Piled Embankments," Geotext. Geomembr., Vol. 29, No. 3, pp. 345-359.

Van Eekelen, S. J. M., Bezuijen, A., Lodder, H. J., and Van Tol, A. F., 2012a, "Model Experiments on Piled Embankments, Part I," Geotext. Geomembr., Vol. 32, pp. 69-81.

Van Eekelen, S. J. M., Bezuijen, A., Lodder, H. J., and Van Tol, A. F., 2012b, "Model Experiments on Piled Embankments, Part II," Geotext. Geomembr., Vol. 32, pp. 82-94.

Van Eekelen, S. J. M., Bezuijen, A., and van Tol, A. F., 2013, "An Analytical Model for Arching in Piled Embankments," Geotext. Geomembr., Vol. 39, pp. 78-102.

Van Eekelen, S. J. M., Bezuijen, A., and van Tol, A. F., 2015, "Validation of Analytical Models for the Design of Basal 
Reinforced Piled Embankments," Geotext. Geomembr., Vol. 43, No. 1, pp. 56-81.

Vardoulakis, I., Graf, B., and Gudehus, G., 1981, "Trap-Door Problem With Dry Sand: A Statical Approach Based Upon Model Test Kinematics," Int. J. Numer. Anal. Met.Geomech., Vol. 5, No. 1, pp. 57-78.

Weiler, W. A. and Kulhawy, F. H., 1982, "Factors Affecting Stress Cell Measurements in Soil," J. Geotech. Eng. Div., Vol. 108, No. 12, pp. 1529-1548.

White, D. J., Take, W. A., and Bolton, M. D., 2003, "Soil Deformation Measurement Using Particle Image Velocimetry (PIV) and Photogrammetry," Geotechnique, Vol. 53, No. 7, pp. 619-631.
Zaeske, D., 2001, "Research on the Behaviour of Unreinforced and Reinforced Bearing Layers on Pile-Like Foundation Elements," Schriftenreihe Geotechnik, University of Kassel, Kassel, Germany (in German), p. 177.

Zaeske, D. and Kempfert, H.-G., 2002, "Calculation and Behaviour of Unreinforced and Reinforced Bearing Layers Over Point- or Line-Shaped Bearing Elements," Bauingenieur, Vol. 77, No. 2, pp. 80-86 (in German).

Zhu, B., Jardine, R. J., and Foray, P., 2009, "The Use of Miniature Soil Stress Measuring Cells in Laboratory Applications Involving Stress Reversals," Soils Found., Vol. 49, No. 5, pp. 675-688. 